\title{
Sudden cardiac death in epilepsy disappoints, but epileptologists keep faith
}

\author{
Apesar do desapontamento com a morte súbita cardíaca nas epilepsias, os epileptologistas \\ mantêm a fé
}

Fulvio A. Scorza', Esper A. Cavalheiro', Jaderson Costa da Costa²

\begin{abstract}
Sudden unexpected death in epilepsy (SUDEP) is the most common cause of death in people with intractable epilepsy. Probably, optimization of seizure control will prevent some of these deaths. Briefly, we integrated in this paper some data about the epidemiology, risk factors, etiology, and preventative measures in the management of SUDEP.
\end{abstract}

Keywords: epilepsy; death, sudden.

\section{RESUMO}

A morte súbita nas epilepsias (SUDEP) é a causa mais comum de morte em indivíduos com epilepsia refratária. Provavelmente, o controle das crises epilépticas irá evitar algumas dessas mortes. Resumidamente, nós descrevemos nesse artigo alguns dados sobre a epidemiologia, fatores de risco, etiologia e medidas preventivas na SUDEP.

Palavras-chave: epilepsia; morte súbita.

The first formal description of sudden cardiac death (SCD) was made as early as $4^{\text {th }}$ century BC by the father of medicine, Hippocrates of Kos, which stated in his aphorisms that those who are subject to frequent and severe fainting attacks without obvious cause die sudden$l y^{1,2}$. Presently, in most textbooks SCD is defined as an unexpected death occurring within one hour from onset of symptoms in an individual with stable clinical conditions before the onset of the life-threatening arrhythmic event ${ }^{3,45}$. The magnitude of the problem is reflected on the fact that more than 7 million lives per year are lost to SCD worldwide ${ }^{1}$. In Europe, approximately 350,000 individuals die each year due to SCD with unsuccessful out-of-hospital cardiopulmonary resuscitation $^{6,7}$. The incidence of SCD in the United States ranges between 180,000 and 450,000 cases annually, depending on the definition used ${ }^{4,5,8,9,10}$. In a more specific way, prospective studies using multiple sources developed in the United States, Netherlands, Ireland, and China have shown that SCD rates ranging from 50 to 100 per 100000 in the general population ${ }^{10,11,12,13,14,15,16}$. The global burden of SCD remains high despite the fact that several factors have already been described which increase the risk of SCD in the general population ${ }^{9,10}$. It should not be ignored that epilepsy and seizures can have a profound effect on cardiovascular function and in some cases may be fa$\operatorname{tal}^{17,18}$. A number of questions should be raise to elucidate clearly the exact relationship between SCD and epilepsy.

WHERE? Epilepsy is one of the most common neurological conditions affecting at least 65 million people worldwide ${ }^{19,20}$. Individuals of all ages can be affected by it. It is treatable but often requires lifelong medication and sometimes surgery to control seizures ${ }^{21,22}$. Despite this, seizures in up to $40 \%$ of people with epilepsy do not respond properly to antiepileptic drugs or other treatments $^{23}$. In these individuals with refractory epilepsy, high rates of premature death compared with the general population have recorded ${ }^{24,25}$. Sudden unexpected death in epilepsy (SUDEP) is a major cause of death in those people ${ }^{26}$. WHAT? The lack of autopsy results and

\footnotetext{
${ }_{1}^{1}$ Universidade Federal de São Paulo, Escola Paulista de Medicina, Disciplina de Neurociência, Departamento de Neurologia/Neurocirurgia, São Paulo SP, Brasil; ${ }^{2}$ Pontifícia Universidade Católica do Rio Grande do Sul, Hospital São Lucas e Instituto do Cérebro do Rio Grande do Sul, Serviço de Neurologia, Porto Alegre RS, Brasil. Correspondence: Fulvio A. Scorza; Rua Pedro de Toledo, 669 / 10 andar; 04039-032 São Paulo SP, Brasil; E-mail: scorza.nexp@epm.br

Conflict of interest: There is no conflict of interest to declare.

Support: This study has been supported by the following grants: FAPESP (Fundação de Amparo à Pesquisa do Estado de São Paulo); CNPq (Conselho Nacional de Desenvolvimento Científico e Tecnológico); Coordenação de Aperfeiçoamento de Pessoal de Nível Superior (CAPES), CEPID/FAPESP; FAPESP/PRONEX and FAPESP/CNPq/MCT (Instituto Nacional de Neurociência Translacional).

Received 06 May 2016; Accepted 16 May 2016.
} 
the rarely witnessed or monitored cases of SUDEP pose difficulties with regard to its pathophysiology and definitions ${ }^{18,27,28,29,30}$. SUDEP is generally defined as sudden, unexpected, witnessed or unwitnessed, nontraumatic and nondrowning death in patients with epilepsy, with or without evidence of a seizure and excluding documented status epilepticus, in which postmortem examination does not reveal a toxicologic or anatomical cause of death ${ }^{31}$. WHEN? The incidence of SUDEP is largely underestimated due to differences in patient populations, study design, incomplete level of documentation and the criteria for diagnosing SUDEP ${ }^{18,27,30,32}$. Over the years, further refinements to knowledge of SUDEP incidence have been made. Briefly, it has been reported that SUDEP is responsible for up to $17 \%$ of all deaths in epilepsy ${ }^{33}$ with an incidence rate among adults between 1:500 and 1:1,000 patient-years while in children SUDEP varies on average 2/10.000 patient-years ${ }^{33,34}$. WHY? Recent research suggests that multiple risk factors may contribute for SUDEP but the by far most important clinical risk factor is the presence and the number of seizures mainly generalized tonic-clonic seizures (GTCS) ${ }^{35}$. Additionally, other potential risk factors for SUDEP that should not be disregarded have also been identified, including young age at epilepsy onset, longer duration of epilepsy, nocturnal seizures, dementia, absence of cerebrovascular disease, asthma, male gender, symptomatic etiology of epilepsy, alcohol abuse, and winter temperatures ${ }^{35,36,37,38}$. HOW? The precise mechanisms of SUDEP remain unknown ${ }^{39}$. It is also paramount to understand the mechanisms underlying SUDEP as it may lead to the identification of previously unrecognized risk factors more amenable to intervention and key to prevention ${ }^{30,33,40}$. Although the cause or causes of SUDEP are still unknown, human and experimental research suggest that the major domains have been attributed to autonomic system, i.e., respiratory and/or cardiovascular abnormalities during and after seizures $^{18,27,39,40,41,42,43}$. From what is known to date, different causal pathophysiological events should be highlighted such as acute cardiovascular changes during seizures (tachyarrhythmias, bradyarrhythmias and ictal asystole), neurogenic pulmonary edema and respiratory disturbances with central and obstructive apnea $17,36,40,42,43,44$.
As described previously, cardiac abnormalities and autonomic dysfunction seem to be at the "heart" of the problem in SUDEP ${ }^{45}$. To this effect, the best approach is that of prevention. It is clear that our understanding of the best way to prevent SUDEP is still incomplete. Although strict evidence for their effectiveness is still lacking, some interesting strategies have been suggested which could be useful in reducing the risk of SUDEP ${ }^{30,40}$. Thus, possible preventive strategies such as good control of seizures, reduction of stress, participation in physical activity and sports, dietary management (e.g., omega-3 supplementation) and supervision at night are already well formed ${ }^{46}$. Besides these aspects, a close convergence between neurologists and other medical specialties, especially cardiologists, it must also be present in the context and constantly encouraged by experts in the SUDEP field ${ }^{41,47,48}$.

Considering the guidelines, we agree with suggestions that patients with epilepsy, especially those at highest risk of SUDEP, should follow the comprehensive cardiovascular screening protocols (ECG, Holter-monitoring, echocardiography, genetic analysis, ergometric exercise test and myocardial scintigraphy, and, if abnormalities were found, coronary angiography) ${ }^{41,49,50}$. Despite this SUDEP mechanisms are still a mystery, and the recent discoveries of genes and molecular systems involved in epilepsy and cardiovascular system $^{41}$ are a cause for optimism that this issue could be solved quicker than anticipated.

Knowledge makes us wiser. In this sense, clinical and animal research is critical to understand accurately the close association between SUDEP and seizures, and obviously, this is the primary goal of decreasing epilepsy-related deaths which figure high each year in mortality statistics.

\section{Acknowledgements}

The authors acknowledge the many valuable suggestions made by Dr Ley Sander, Professor of Neurology and Clinical Epilepsy, UCL Institute of Neurology, Honorary Consultant Neurologist at the National Hospital for Neurology and Neurosurgery, Queen Square, London, UK and Director for Scientific Research at SEIN - Stichting Epilepsie Instellingen Nederland in Heemstede, Netherlands.

\section{References}

\footnotetext{
1. Abhilash SP, Namboodiri N. Sudden cardiac death: historical perspectives. Indian Heart J. 2014;66 Suppl 1:S4-9. doi:10.1016/j.ihj.2014.01.002

2. Mirchandani S, Phoon CK. Sudden cardiac death: a 2400-year old diagnosis? Int J Cardiol. 2003;90(1):41-8. doi:10.1016/S0167-5273(02)00517-X

3. Priori SG. Genetic testing to predict sudden cardiac death: current perspectives and future goals. Indian Heart J. 2014;66:S58-60. doi:10.1016/j.ihj.2013.11.004
}

4. Engelstein ED, Zipes DP. Sudden cardiac death. In: Alexander RW, Schlant RC, Fuster V, editors. The heart, arteries and veins. New York: McGraw-Hill; 1998. p. 1081-112.

5. Myerburg RJ, Castellanos A. Cardiac arrest and sudden death. In: Braunwald E, editors. Heart disease: a textbook of cardiovascular medicine. Philadelphia:WB Saunders; 1997. p. 742-9.

6. Gräsner JT, Bossaert L. Epidemiology and management of cardiac arrest: what registries are revealing. Best Pract Res Clin Anaesthesiol. 2013;27(3):293-306. doi:10.1016/j.bpa.2013.07.008 
7. Böttiger BW, Gräsner JT, Castren M. Sudden cardiac death: good perspectives with this major health care issue. Intensive Care Med. 2014;40(6):907-9. doi:10.1007/s00134-014-3319-3

8. Lloyd-Jones D, Adams RJ, Brown TM, Carnethon M, Dai S, De Simone G et al. Heart disease and stroke statistics - 2010 update: a report from the American Heart Association. Circulation. 2010;121(7) e46-215. doi:10.1161/CIRCULATIONAHA.109.192667

9. Zipes DP, Wellens HJ. Sudden cardiac death. Circulation. 1998;98(21):2334-51. doi:10.1161/01.CIR.98.21.2334

10. Deo R, Albert CM. Epidemiology and genetics of sudden cardiac death. Circulation. 2012;125(4):620-37. doi:10.1161/CIRCULATIONAHA.111.023838

11. Nichol G, Thomas E, Callaway CW, Hedges J, Powell JL, Aufderheide TP et al. Regional variation in out-of-hospital cardiac arrest incidence and outcome. JAMA. 2008;300(12):1423-31. doi:10.1001/jama.300.12.1423

12. Chugh SS, Jui J, Gunson K, Stecker EC, John BT, Thompson B et al. Current burden of sudden cardiac death: multiple source surveillance versus retrospective death certificate-based review in a large U.S. Community. J Am Coll Cardiol. 2004;44(6):1268-75. doi:10.1016/j.jacc.2004.06.029

13. Vreede-Swagemakers JJ, Gorgels AP, Dubois-Arbouw WI, Ree JW, Daemen MJ, Houben LG et al. Out-of-hospital cardiac arrest in the 1990's: a population-based study in the Maastricht area on incidence, characteristics and survival.J Am Coll Cardiol. 1997;30(6):1500-5. doi:10.1016/S0735-1097(97)00355-0

14. Byrne R, Constant O, Smyth Y, Callagy G, Nash P, Daly Ket al. Multiple source surveillance incidence and aetiology of out-of-hospital sudden cardiac death in a rural population in the West of Ireland. Eur Heart J. 2008;29(11):1418-23. doi:10.1093/eurheartj/ehn155

15. Hua W, Zhang LF, Wu YF, Liu XQ, Guo DS, Zhou HL et al. Incidence of sudden cardiac death in China: analysis of 4 regional populations. J Am Coll Cardiol. 2009;54(12):1110-8. doi:10.1016/j.jacc.2009.06.016

16. Fishman GI, Chugh SS, DiMarco JP, Albert CM, Anderson ME, Bonow RO et al. Sudden cardiac death prediction and prevention report from a National Heart, Lung, and Blood Institute and Heart Rhythm Society workshop. Circulation. 2010;122(22):2335-48. doi:10.1161/CIRCULATIONAHA.110.976092

17. Jansen K, Lagae L. Cardiac changes in epilepsy. Seizure. 2010;19(8):455-60. doi:10.1016/j.seizure.2010.07.008

18. Devinsky O. Sudden, unexpected death in epilepsy. N Engl J Med. 2011;365(19):1801-11. doi:10.1056/NEJMra1010481

19. Banerjee PN, Filippi D, Hauser WA. The descriptive epidemiology of epilepsy: a review. Epilepsy Res. 2009;85(1):31-45. doi:10.1016/j.eplepsyres.2009.03.003

20. Moshé SL, Perucca E, Ryvlin P, Tomson T. Epilepsy: new advances. Lancet. 2015;385(9971):884-98. doi:10.1016/S0140-6736(14)60456-6

21. Forsgren I, Beghi E, Ekman M. Cost of epilepsy in Europe. Eur J Neurol. 2005;12(Suppl s1):54-8. doi:10.1111/j.1468-1331.2005.01191.x

22. Allers K, Essue BM, Hackett ML, Muhunthan J, Anderson CS, Pickles Ket al. The economic impact of epilepsy: a systematic review. BMC Neurol. 2015;15(1):245. doi:10.1186/s12883-015-0494-y

23. Laxer KD, Trinka E, Hirsch LJ, Cendes F, Langfitt J, Delanty N et al. The consequences of refractory epilepsy and its treatment. Epilepsy Behav. 2014;37:59-70. doi:10.1016/j.yebeh.2014.05.031

24. Nashef L, Ryvlin P. Sudden unexpected death in epilepsy (SUDEP): update and reflections. Neurol Clin. 2009;27(4):1063-74. doi:10.1016/j.ncl.2009.08.003

25. Duncan JS, Sander JW, Sisodiya SM, Walker MC. Adult epilepsy. Lancet. 2006; 367(9516):1087-100. doi:10.1016/S0140-6736(06)68477-8

26. Novak JL, Miller PR, Markovic D, Meymandi SK, DeGiorgio CM. Risk assessment for sudden death in epilepsy: the SUDEP-7 inventory. Front Neurol. 2015;6:252. doi:10.3389/fneur.2015.00252
27. Stöllberger C, Finsterer J. Cardiorespiratory findings in sudden unexplained/unexpected death in epilepsy (SUDEP). Epilepsy Res. 2004;59(1):51-60. doi:10.1016/j.eplepsyres.2004.03.008

28. Langan Y, Nashef L, Sander JW. Sudden unexpected death in epilepsy: a series of witnessed deaths. J Neurol Neurosurg Psychiatry. 2000;68(2):211-3. doi:10.1136/jnnp.68.2.211

29. Lamberts RJ, Thijs RD, Laffan A, Langan Y, Sander JW. Sudden unexpected death in epilepsy: people with nocturnal seizures may be at highest risk. Epilepsia. 2012;53(2):253-7. doi:10.1111/j.1528-1167.2011.03360.x

30. Scorza FA, Cysneiros RM, Albuquerque M, Scattolini M, Arida RM. Sudden unexpected death in epilepsy: an important concern. Clinics (Sao Paulo). 2011;66(Suppl 1):65-9. doi:10.1590/S1807-59322011001300008

31. Nashef L. Sudden unexpected death in epilepsy: terminology and definitions. Epilepsia. 1997;38(Suppl s11):S6-8. doi:10.1111/j.1528-1157.1997.tb06130.x

32. Nei M, Hays R. Sudden unexpected death in epilepsy. Curr Neurol Neurosci Rep. 2010;10(4):319-26. doi:10.1007/s11910-010-0116-4

33. Schuele SU, Widdess-Walsh P, Bermeo A, Lüders HO. Sudden unexplained death in epilepsy: the role of the heart. Cleve Clin J Med. 2007;74(Suppl 1):S121-7. doi:10.3949/ccjm.74.Suppl_1.S121

34. Donner EJ, Smith CR, Snead OC 3rd. Sudden unexplained death in children with epilepsy. Neurology. 2001;57(3):430-4. doi:10.1212/WNL.57.3.430

35. Tomson T, Surges R, Delamont R, Haywood S, Hesdorffer DC. Who to target in sudden unexpected death in epilepsy prevention and how? Risk factors, biomarkers, and intervention study designs. Epilepsia. 2016;57(Suppl S1):4-16. doi:10.1111/epi.13234

36. Hesdorffer DC, Tomson T. Sudden unexpected death in epilepsy: potential role of antiepileptic drugs. CNS Drugs. 2013;27(2):113-9. doi:10.1007/s40263-012-0006-1

37. Hesdorffer DC, Tomson T, Benn E, Sander JW, Nilsson L, Langan $Y$ et al. Combined analysis of risk factors for SUDEP. Epilepsia. 2011;52(6):1150-9. doi:10.1111/j.1528-1167.2010.02952.x

38. Scorza FA, Terra VC, Arida RM, Scorza CA, Cavalheiro EA. Sudden unexpected death in epilepsy and winter temperatures: it's important to know that it's c-c-c-c-cold outside. Epilepsy Behav. 2009;14(4):707. doi:10.1016/j.yebeh.2009.01.009

39. Massey CA, Sowers LP, Dlouhy BJ, Richerson GB. Mechanisms of sudden unexpected death in epilepsy: the pathway to prevention. Nat Rev Neurol. 2014;10(5):271-82. doi:10.1038/nrneurol.2014.64

40. Tomson T, Nashef L, Ryvlin P. Sudden unexpected death in epilepsy: current knowledge and future directions. Lancet Neurol. 2008; 7(11): 1021-31. doi: 10.1016/S1474-4422(08)70202-3

41. Goldman AM, Behr ER, Semsarian C, Bagnall RD, Sisodiya S, Cooper PN. Sudden unexpected death in epilepsy genetics: molecular diagnostics and prevention. Epilepsia. 2016;57 Suppl 1:17-25. doi:10.1111/epi.13232

42. Goldman AM. Mechanisms of sudden unexplained death in epilepsy. Curr Opin Neurol. 2015;28(2):166-74. doi:10.1097/WC0.0000000000000184

43. Surges R, Thijs RD, Tan HL, Sander JW. Sudden unexpected death in epilepsy: risk factors and potential pathomechanisms. Nat Rev Neurol. 2009;5(9):492-504. doi 10.1038/nrneurol.2009.118

44. So EL, Sam MC, Lagerlund TL. Postictal central apnea as a cause of SUDEP: evidence from near-SUDEP incident. Epilepsia. 2000;41(11):1494-7. doi:10.1111/j.1528-1157.2000.tb00128.x

45. Jehi L. Sudden death in epilepsy, surgery, and seizure outcomes: the interface between heart and brain. Cleve Clin J Med. 2010;77(Suppl 3):S51-5. doi:10.3949/ccjm.77.s3.09

46. Scorza FA, Arida RM, Terra VC, Cavalheiro EA. What can be done to reduce the risk of SUDEP? Epilepsy Behav. 2010;18(3):137-8. doi:10.1016/j.yebeh.2010.04.046 
47. Scorza FA, Terra VC, Albuquerque M, Cavalheiro EA. Respiratory findings in sudden unexpected death in epilepsy: a point of convergence for clinical pulmonologists and neurologists. J Bras Pneumol. 2009;35(6):613-4. doi:10.1590/S1806-37132009000600015

48. Scorza FA, Arida RM, Cavalheiro EA. Cardiovascular abnormalities in patients with epilepsy receiving renal replacement therapy with dialysis: a true convergence of clinical cardiology, nephrology and neurology. Nephrol Dial Transplant. 2008;23(5):1775-6. doi:10.1093/ndt/gfn017
49. Goldman AM. Basic mechanisms of SUDEP: human studies. In: Chapman D, Panelli R, Hanna J, Jeffs T, editors. Sudden unexpected death in epilepsy: continuing the global conversation. Camberwell: Epilepsy Bereaved and SUDEP Aware; 2011.

50. Tigaran S, Mølgaard H, McClelland R, Dam M, Jaffe AS. Evidence of cardiac ischemia during seizures in drug refractory epilepsy patients. Neurology. 2003;60(3):492-5. doi:10.1212/01.WNL.0000042090.13247.48 